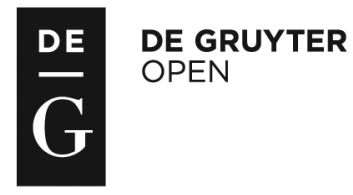

\author{
Administration, vol. 63, no. 4 (2016), pp. 25-36 \\ doi: 10.1515/admin-2016-0003
}

\title{
Local government, 2015
}

\author{
Bríd Quinn \\ University of Limerick
}

For local government in Ireland, 2015 was a year of consolidation as the new structures and processes emanating from Putting People First and the Local Government Reform Act, 2014, became embedded. Public participation networks (PPNs) and their linkage groups and local community development committees began to make their mark during 2015. The municipal/metropolitan district (MD) structures and processes also became more visibly implanted. While the numbers employed in the local government sector remain low, reflecting the 22 per cent drop since 2008, limited recruitment took place during 2015, which served as a morale booster in the sector. New CEOs were appointed in a number of counties and PPN officers were appointed by all local authorities. Shared services continued to be developed. A Department of Public Expenditure and Reform review found that 56 per cent of local authority employees received shared services of some form. A payroll and superannuation system, MyPay, was also rolled out in local authorities during the year. Thus, reform continued, albeit not at the same pace as 2014. This review highlights general and specific developments in the local government sector during 2015.

\section{Reviewing the situation}

Comprehensive measures were put in place to review the effectiveness of the 2014 reforms. The Minister for the Environment, Community and Local Government, Alan Kelly, TD, initiated a two-pronged review process. A Local Government Advisory Group was established 
to consider the operation of the revised local government structures and arrangements, particularly the operation of MDs; to review the ongoing implementation of the local government reform programme; and to provide ongoing advice, views or proposals.

A Local Government Forum was also created to provide an arena for engagement with local authority members on policy and governance matters. Consisting of elected representatives and members of the advisory group, it is focused on maximising effectiveness in local authority governance. The forum is taking steps to ascertain the views of local authority members regarding the effect of local government reforms. It will also serve as a conduit for input by local authority members on aspects of national policy. Surveys are being carried out by the advisory group and by the Association of Irish Local Government (AILG) in conjunction with the forum. The creation of these two appraisal structures to carry out an 'operational review' of the reforms is a constructive step and should yield useful insights about the successes and deficiencies of the reformed system of local government.

A draft Framework Policy for Local and Community Development in Ireland was published in April and submissions on the draft were sought. The policy, when finalised, will provide the foundation upon which state policies, programmes and interventions for local and community development will be developed and implemented. Many PPNs discussed the draft at open meetings. All these actions indicate that reform of the local governance system and processes is continuing.

During 2015 boundary reviews were initiated in Athlone, Carlow, Drogheda and Waterford. The reports are expected to be finalised in March 2016. The review committees will make recommendations on how best to achieve effective and convenient local government in the four areas.

More controversial were the reviews regarding possible local authority mergers. The Cork Local Government Review (CLGR) committee was established by the minister in January 2015, and published its findings in September. While three of the five committee members recommended merging the city and county councils, two of the members co-authored a minority report opposing a merger and recommending a city boundary extension. The report was given a mixed reaction. A majority of county council members supported the merger proposal but the city council vehemently opposed it. Accordingly, Cork City councillors moved a Section 140 resolution 
instructing the chief executive to seek a judicial review of the CLGR group's administrative actions, making the city council the first local authority to challenge the constitutionality of government policy on the mergers of local authorities.

A review committee was also appointed to review the merits of merging Galway City and County Councils. It published a 'deliberation report' in August and sought submissions on the most appropriate and efficient structure to maximise service delivery and economic progress for Galway. The final report is awaited but is unlikely to be published before the 2016 general election.

\section{The financial dimension}

Many changes in the financial sphere were evident in 2015 as funding challenges continued. Government spending in Ireland continues to be the most centralised in Europe, with less than 10 per cent of government expenditure undertaken by local government (Boyle, 2015). Total gross budgeted expenditure in 2015 was estimated at $€ 5.16$ billion by the Local Government Auditor (Department of the Environment, Community and Local Government, 2015). A report found the overall revenue account credit balance for the sector to be $€ 3,361,659$, showing deterioration of $€ 30,928,280$ from 2010 (NOAC, 2015a). With such a significant drop, it is not surprising that the report also identified seventeen local authorities which are in a deficit situation, while only fourteen showed a surplus. Yet there was a significant reduction in the indebtedness of local authorities during 2015 as a result of prudent spending.

The timing of the local authority budget cycle was adjusted during 2015 , in order to streamline the budgetary process and reinforce the role of MDs. SI No. 363/2015 prescribes that the meeting at which MD members consider the draft budgetary plan must conclude no later than ten days prior to the local authority budget meeting, facilitating greater consideration of the budget.

The first full year of the Local Property Tax (LPT) brought about changes in spending and budgeting processes. Much was learned about the implications of varying LPT rates during implementation of the 2015 allocations. Consequently, when the list of proposed LPT rates for 2016 was published, it showed noteworthy changes from the 2015 rates. Only the four Dublin councils and Clare are implementing the full 15 per cent reduction in 2016. Cork City will reduce the rate by 10 per cent, and Cork County by 5 per cent. Kildare and Monaghan 
will implement 7.5 per cent reductions, Longford a 3 per cent reduction and Louth a 1.5 per cent reduction. All remaining authorities will apply the full tax rate. Five local authorities are increasing their LPT rates for 2016 over those that applied in 2015, namely Cork County, Limerick, Mayo, Westmeath and Wicklow. Thus, local councils are availing of their prerogative to vary the LPT but fewer are reducing it than might have been expected from the political reaction when the local adjustment factor was first announced.

Nineteen local authorities benefited from the Local Government Equalisation Fund in 2015, with Donegal, for example, receiving just under $€ 14$ million and Tipperary around $€ 13$ million. The fund ensured financial support to councils whose receipts for the LPT would be less than their general purpose grant allocation for 2014, thereby enabling them to continue to maintain provision of public services.

The valuation system for the LPT received further attention during 2015. Amid concerns that rising property prices in Dublin could lead to significant increases in the amount of tax paid by homeowners, the government commissioned a report on possible reforms of the LPT (Thornhill, 2015). The report recommended delaying the revaluation of property for the tax until 2019, a recommendation subsequently adopted by government.

Progress was made with regard to tax harmonisation within counties which had previously been the location of town councils. The Local Government Reform Act, 2014, provided for rates harmonisation to cater for differences between annual rates on valuation (ARVs) of towns and counties in the twenty-one local authority areas where town authorities had previously existed. In 2015 a 'base year adjustment' mechanism came into effect and will phase in increases and decreases in the ARV over a maximum of ten years. The aim in 2015 was to ensure that ratepayers would not pay any more (or less) in 2015 than they did in 2014. However, some local councils chose to accelerate the harmonisation, with, for example, Longford County Council opting to carry out full harmonisation in 2015 at a cost of $€ 110,000$. Clare County Council voted to effect harmonisation over a two-year period from 2016 rather than over the ten years permitted by the Department of the Environment, Community and Local Government (DECLG). Accordingly, harmonisation speeds will vary considerably.

The National Oversight and Audit Commission (NOAC) began to have an effect in 2015, both nationally and within local authorities and their audit committees. It published its work plan for 2015-16, 
engaged with local authorities and audit committees, and carried out research and analysis. In December 2015 it published reports on performance indicators in local authorities and reviewed local authority corporate plans for 2015-19. It also undertook a customer satisfaction survey of local authority tenants and published the results. The performance indicators review generated comparative information about how local authorities perform in delivering services. It includes a quality assurance review of seven indicators, highlights key messages emerging from the data and makes wide-ranging recommendations. Among the interesting findings was the per capita cost of the planning service, which varied from $€ 12.66$ in County Cork to $€ 53.19$ per head in Roscommon. While NOAC was generally satisfied with the adequacy of corporate plans, it noted the significant variations in the approaches followed by local authorities, assessing such variations to be 'indicative of scope to improve the quality of, and commitment to, corporate planning in some areas' (NOAC, 2015b, p. 18). The tenant survey found that, of those living in council estates, 85 per cent consider their estate to be a pleasant place to live. This was a welcome finding. Further reports on issues such as revenue collection and quality assurance reporting were undertaken by NOAC, and will be published early in 2016 .

Many funding opportunities were made available to local authorities and communities during 2015, as the examples below indicate. The Minister for Communications, Energy and Natural Resources, Alex White, TD, awarded grants worth a total of $€ 18.6$ million to twenty-nine community energy efficiency initiatives, with a key role for local authorities in supporting the initiatives. The projects will improve the energy efficiency of 2,435 homes and 400 public, private and community buildings, and are expected to deliver lifetime energy savings of $€ 140$ million in the localities concerned.

The Local Agenda 21 Environmental Partnership Fund saw almost $€ 400,000$ being provided by the DECLG, with matching funding from local authorities. This grant scheme promotes sustainable development, and in 2015 over 770 small-scale, non-profit environmental projects at local level were supported.

In July the Designated Urban Centres Grants Scheme 2014-2020 was launched in conjunction with the Southern Regional Assembly and the Northern and Western Regional Assembly. The scheme will enable investments in Irish urban centres of $€ 80$ million for the period 2014-20. It will involve European Regional Development Fund funding of approximately $€ 40$ million with matching funding from the 
local authorities. The scheme aims to increase the development potential of designated Irish urban centres by investing in, and enhancing, their economic, social and environmental conditions.

\section{Housing and planning}

Housing continued to be a major issue during 2015. In April the DECLG announced housing targets for each local authority area for 2015-17. Over $€ 1.5$ billion will be invested in a combination of building, buying and leasing schemes involving local authorities. A major social housing construction programme was announced on 5 May, with $€ 312$ million in investment covering all local authorities and with over 1,700 housing units to be built. In July a further investment of over $€ 180$ million was announced in order to deliver over 1,100 new social housing units, including new housing units for homeless persons, for the elderly and for people with disabilities. Other measures to alleviate the housing crisis were announced in November. They included a targeted rebate of development contributions in Dublin and Cork for housing at certain price levels, new national apartment planning guidelines and some changes to the operation of strategic development zones.

Also in November, new regulations (SI No. 484 of 2015) were introduced regarding the sale of local authority houses to tenants and enabling authorities to advance loans to tenants for the purchase of houses under the new scheme. The National Asset Management Agency (NAMA) played a significant role in dealing with local authority housing shortages during 2015. By the end of October, NAMA had identified over 6,575 residential properties as potentially suitable for social housing. Demand was confirmed by local authorities for over 2,500 of those properties, and over 1,600 have now been delivered for social housing use.

Measures were also taken to improve the situation of tenants and to incentivise landlords to accommodate local authority tenants. A New Deal for Tenants, launched by Minister Kelly in November, provides for rent certainty by increasing the rent-review period from one to two years, introducing increased notice periods for rent reviews and providing greater protections for tenants. Housing assistance payment limits are being increased in Cork, Galway, Kildare and Meath, where flexibility allows for a 20 per cent payment above rent supplement thresholds. A tax relief measure was introduced in the Finance Act to allow landlords who lease to tenants in receipt of social housing 
supports to avail of 100 per cent mortgage interest relief on their borrowings when they commit to accommodating such tenants for a minimum period of three years.

The various measures combine to begin to address the problems with the mismatch between housing supply and demand, as well as problems in the private rental sector and problems regarding homelessness and the limited availability of affordable housing.

In December Minister Kelly published an independent planning review of the performance of planning functions in six planning authorities and the department's response to the recommendations, which includes a schedule to implement all recommendations of the report through appropriate legislative, regulatory and policy-level changes.

\section{Water, water, water!}

During 2015 Irish Water continued to expand its functioning as the national water utility, and local authorities saw further adjustments regarding the provision of water supplies and the management of water assets. A number of statutory instruments were issued to enable transfer of properties from the water services authorities to Irish Water. Local authorities will continue to bill non-domestic customers as agents of Irish Water until a new regime is put in place.

The task of moving to water service delivery by a single, public national utility proved more complex than anticipated and controversy about water-related issues emerged in various contexts. Among the issues pertaining to Irish Water was the decision by Eurostat not to treat it as a state-owned commercial entity, meaning that it has to be classified as part of the government sector in accounting for debt and deficit figures. Irish Water also became embroiled in a row with local authorities and the Environmental Protection Agency over who is responsible for up to 200 small drinking water plants across the country. In February the Public Accounts Committee was informed that Irish Water would receive $€ 399$ million from the Local Government Fund during 2015. There was public and political discontent in July when it was revealed that Irish Water had only collected 46 per cent of the revenue due in water charges. November saw controversy about possible privatisation of Irish Water in the future. Subsequently, local government staff working under the management of Irish Water voted for industrial action. Meanwhile, protests about water charges continued unremittingly, with thousands 
marching on a number of occasions during the year and a massive flag protesting against water charges being displayed during a semi-final at Croke Park. The charges are a frequent topic among local councillors and are expected to be a controversial issue in the lead up to the general election.

Unprecedented flooding during December caused major problems for local authorities. While their unstinting response to the crisis earned local praise, there were problems regarding flood management and resource issues. A total of $€ 8$ million was allocated to local authorities to help deal with the impact of the floods but public disquiet prevailed, and local authorities are faced with significant costs and resource issues in the aftermath of the flooding.

\section{Regional issues}

In January three regional assemblies came into being - the Southern Regional Assembly, the Northern and Western Regional Assembly, and the Eastern and Midland Regional Assembly. Among their functions are the promotion of effective local government and public services in the regions in conjunction with NOAC. Also in January, eighteen local politicians (nine members and nine alternates) were formally appointed to the European Committee of the Regions. They also became members of the regional assemblies, if not already nominated to those bodies.

Within each assembly area, the region is further subdivided into 'strategic planning areas', which broadly equate to the NUTS III regions. The new regional structures will have a prominent role in the emerging planning hierarchy. Each regional assembly will prepare a regional spatial and economic strategy, in conjunction with preparation of the national planning framework. The city and county development plans and the local economic and community plans will feed into the regional and national strategies. This alignment of spatial and economic planning at various levels will be beneficial but challenging for local authorities.

New regional arrangements for waste management also came into effect during 2015. Cork County Council, Dublin City Council, and Leitrim and Donegal County Councils (in a combined bid) were selected as the new waste enforcement regional lead authorities (WERLAs) for the Southern, Eastern and Midlands, and Connacht /Ulster Regions, respectively. Each of these new WERLAs will have responsibility for coordinating waste enforcement actions within 
regions, setting priorities and common objectives for waste enforcement, and ensuring consistent enforcement of waste legislation across the three existing waste management planning regions. Local authority personnel will continue to act as first responders to specific breaches of waste legislation. The work of the WERLAs will be overseen by a national steering committee, which will establish national waste enforcement priorities for the WERLAs.

\section{Rural developments}

The way in which local and rural development interventions are implemented in sub-regional areas was reconfigured as part of the reform drive. This was part of the government's strategy to improve coordination and ensure that local government is positioned to lead local and rural development interventions. On 10 March Minister Kelly and the Minister of State with Special Responsibility for Rural Affairs, Ann Phelan, TD, announced the county allocations for the LEADER elements of the Rural Development Programme. Over $€ 220$ million was allocated to individual sub-regional (county) areas for implementation of the LEADER elements of the Rural Development Programme by local action groups within those areas. Subsequently, the local action groups prepared local development strategies. Speaking at the announcement, Minister Kelly said, 'I also believe the ongoing work at a local level as outlined in the Government's reform programme Putting People First will serve only to improve the impact of LEADER funding in rural communities' (Kelly, 2015b).

In September $€ 30$ million was announced for the Village and Town Renewal Scheme, which will support the revitalisation of rural towns and villages with the aim of improving the living and working environment in rural communities and enhancing their potential to support increased economic activity into the future. On 29 September Minister Phelan announced $€ 3,758,479$ in funding for the rural economic development zones pilot scheme. These zones are functional, rather than administrative, areas that reflect the spatial patterns of local economic activity and development processes. This pilot scheme was prompted by the report of the Commission for the Economic Development of Rural Areas, which identified the need to take a more bespoke approach to planning at regional and local levels, and advocated that planning should not be restricted by administrative boundaries. 
These different measures are significant for Ireland's rural areas, and their implementation will bring together administrators, councillors and communities in a concerted effort to achieve more effective, coordinated systems of local and rural development within the reformed local government landscape.

\section{Awards and recognition}

The work of local authorities was acknowledged in various fora. Clare County Council became the first local authority in Ireland to achieve certification to the new Excellence Through People international business standard. This standard provides a business improvement model for organisations to enhance performance and realise strategies through the management and development of their people. Further international recognition came when Publicpolicy.ie's interactive website Localauthorityfinances.com won in its category of e-Government \& Open Data at the World Summit Awards (WSA). The site was also selected by the WSA Grand Jury as the best and most innovative digital innovation with high impact on society 2015.

Annual awards ceremonies recognised and affirmed the innovative work of local authorities. The Local Authority Members' Association (now AILG) selected Tipperary County Council as its Council of the Year. Cavan Burren Park won the Best Heritage Project, while the title of Emergency Response Person/Team of the Year was given to Bundoran RNLI Lifeboat Station, and the Most Innovative Authority title was awarded to South County Dublin for its county development plan public consultation process. Among the Chambers Ireland Excellence in Local Government awards were Cork City Council for their economic development initiative I WISH (Inspire young Women to Investigate opportunities in Stem) and Carlow County Council for their Tourism Planning and Execution scheme.

\section{Ethics, transparency, accountability and lobbying issues}

The Regulation of Lobbying Act, 2015, came into effect on 1 September and covers the lobbying of local councillors as well as ministers, TDs, senators, MEPs, special advisers and designated public officials. Also published were specific guidelines regarding lobbying about the zoning or development of land. The regulations are expected to enhance transparency and have implications at local level for elected councillors and local authority officials. Each local 
authority must list and publicise their designated public officials, who are usually at director of service level or higher.

In the aftermath of a Standards in Public Office (SIPO) investigation, legislative change was brought about through SI 29/2015, obliging councillors to have regard to the Code of Conduct for Councillors, which they must declare they have read and understood. The regulation also stipulates the classes of local authority employees to whom the provisions of Part 15 of the Local Government Act, 2001, regarding an ethical framework, apply, and prescribes the annual declaration form to be furnished by relevant employees and members of local authorities. A local authority's ethics register must now include accurate records of the supply of copies of codes of conduct for all members and staff.

Further controversy arose regarding ethical issues when a December Prime Time programme used covertly obtained material to support allegations that a minority of councillors were using their position for financial and/or personal gain. Fortuitously, a bill aiming to overhaul the political ethics system was brought to the Oireachtas the following week. It will allow for a Public Sector Standards Commissioner to replace SIPO and to oversee a reformed complaints and investigations process.

Councillors were also in the news when freedom of information enquiries revealed the variations in the amount of expenses claimed by some of them. Despite the provisions of the Local Government Reform Act, 2001, aimed at improving the transparency and accountability of the system, public perception of the amounts claimed was negative, although there is recognition that the workload of councillors has increased following the 2014 reforms.

\section{Conclusions}

The changing role of local government, resulting from the 2014 reforms, is particularly focused on promoting economic development and social progress, including the well-being of communities. The year 2015 witnessed local authorities embracing that role and asserting themselves as the key vehicle for local delivery of national policies. There was also an emphasis on fostering sustainable local and community development and the well-being of communities. These themes found universal support at national and European levels, as well as among local actors. Much of the rancour of 2014 among councillors and between local development activists and local 
authorities dissipated, and positive working relationships were developed in order to address the social, environmental and economic challenges confronting those involved in local governance. In a January press release Minister Kelly articulated an ambition for local government to be the 'Engine Behind Recovery' (Kelly, 2015a). This ambition has not quite been achieved and, although progress was made during 2015, challenges persist.

\section{References}

Boyle, R. (2015). Public sector trends 2015. Dublin: Institute of Public Administration.

Department of Public Expenditure and Reform. (2015). An examination of shared services in the Irish public service and internationally. Retrieved from www.per.gov.ie/en/research-into-shared-services-in-irish-public-service [29 December 2015].

Department of the Environment, Community and Local Government. (2015). Local authority budgets 2015. Retrieved from www.environ.ie/en/Local Government/FileDownLoad,42097, en.pdf [11 October 2015].

Kelly, A. (2015a). Local government to be the 'engine behind recovery' with key reforms - Minister Kelly [Press Release]. Retrieved from http://www. environ.ie/en/LocalGovernment/LocalGovernmentReform/News/MainBo dy,40085,en.htm [20 January 2016].

Kelly, A. (2015b) Ministers Kelly \& Phelan launch $€ 250$ million Rural Development Programme [Press Release]. Retrieved from http://www.environ.ie/en/Community/RuralDevelopment/News/Main Body,40931,en.htm [20 January 2016].

NOAC. (2015a). Annual report 2014. Retrieved from http://noac.ie/?s= annual+report [10 December 2015].

NOAC. (2015b). Corporate plans report NOAC. Retrieved from noac.ie/noacreports/ [10 December 2015].

Thornhill, D. (2015). Review of the local property tax (LPT). Retrieved from http://www.budget.gov.ie/Budgets/2016/Documents/Review_of_Local_ Property_Tax_pub.pdf [10 December 2015]. 